\title{
The Devil in the House: The Awakening of Chopin's Anti-Hero
}

\author{
Bahareh Azad \\ Department of English Language, Faculty of Foreign Languages, University of Isfahan, Daneshgah \\ Street, Azadi Square - 8174673441, Iran \\ E-mail address: Baharazad125@gmail.com
}

\begin{abstract}
The mythic quality of Kate Chopin's The Awakening (1899) derives from recurrent images of archetypal symbols such as sea, sun, and journey, accompanied by up/down motif representing death and rebirth. Having been decanonized for infringing the traditional codes of marriage and motherhood, Chopin's work, this study proves, violates yet another convention, that of the mythological theorists, namely Joseph Campbell's. Being a female principle as opposed to Campbell's macho hero, Chopin's protagonist, Edna undergoes the same archetypal pattern of quest, initiation, and descent into the underworld. In her archetypal passage from innocence to experience, however, and through rebellious acts of self-expression, viz. painting, music, gambling, and extra-marital relationships, the heroine not only ceases serving the interest of the society which has reduced her to the position of an object to be possessed by husband or devoured by children but also challenges its core values, overturning the fairy tale of "the angel in the house." And while having inherited the narcissistic characteristic of the conventional hero, Edna turns more into the heroine of the self than of the community, who in ultimate defiance of the romantic ideal of ever-victorious heroes chooses not to ascend from the underworld but to abort the last phase of the heroic mission and, thus, differentiates Chopin's modernist representation of the realistic heroine from the idealistic portrayals of the male hero in the mythological canon.
\end{abstract}

Keywords: The Awakening; Kate Chopin; archetypal criticism; the myth of the hero; Carl Jung; Joseph Campbell

\section{INTRODUCTION}

Rebuked for its stimulation of "unholy imaginations and unclean desires" (Knights 44), Kate Chopin's The Awakening (1899) remained the transgressor of bounds of decency and normality. "Though acknowledged as a 'brilliant piece of writing"" it was considered as 'essentially vulgar', 'morbid', 'repellent', even 'nauseating' and 'gilded dirt' that left one 'sick of human nature," Heilmann reflects (88). Regrettably even now the critical appraisal of the novel suffers a narrow perception of its thematics and techniques. Far from being a mere feminist manifesto of woman's rights, Chopin's work explores universal theme of individuation, in Jung's terminology (Jung 35). As Jung theorizes, the self, an ideal towards which the individual constantly strives but is never capable of attaining represents the wholeness of personality (Adamaski 265). Being resulted from the union of all parts of the psyche, the Self comprises the space to embrace even its undesirable and suppressed aspects. Of the psyche's most unwelcome elements is the 'shadow,' which in close cooperation with 
the 'persona,' the contrasting social mask, constitutes the archetype with "the strongest impact on the human being" (265). Originating from what Jung denominates as the collective unconscious, the shadow is judged to be the reservoir of unsought instincts (265). This collective unconscious is framed by "instincts and archetypes that are symbols, signs, patterns of behavior, and thinking and experiencing" based on mythological models "inherited from our ancestors" (263).

Campbell, another critic analyzing the appearance of symbols and archetypes in myths, focuses upon the hero's journey of (self-)discovery. The departure-initiation-return scheme of the hero myth is shared among nearly all cultures (Zhang 4), he observes in great accord with Jungian notion of collective unconscious which defines the recurrence of certain images and symbols, namely archetypes. Employing a combination of both approaches to The Awakening illustrates Chopin's modernity of technique and novelty of theme.

\section{ARGUMENT}

"Would it have been better had Mrs. Kate Chopin's heroine slept on forever and had never had an awakening?" (New York Times)

The Awakening is as much feminist as it is universal. Being the exemplar of the universal hero (ine), Edna's journey of self-discovery touches the collective realm of human experience. Referring to Edna's psychic self-gratification, Bloom asserts: "The autoerotic seems to be a realm where, metaphorically anyway, there are no major differences between male and female seers" (3). Confrontation with the unconscious is an individual act of heroism, but the temptation of losing one's self would be too hard to resist, Chopin warns. Edna's first daring attempt at self-exploration occurs when learning swimming in the sea: "As she swam she seemed to be reaching out for the unlimited in which to lose herself" (Chopin 32). Her attachment to the safe conscious grounds, though, saves her: "Once she turned and looked toward the shore, toward the people she had left there.... A quick vision of death smote her soul, and for a second of time appalled and enfeebled her senses. But by an effort she rallied her staggering faculties and managed to regain the land" (32).

The Awakening's universal resonance is determined by its orientation towards myth and mythologizing of the ideal of romantic love. Edna is the prototype of the romantic heroine; as Ringe has pointed out the novel's reference to her reading Emerson reveals the character's urge for transcendence (581). Moreover, the sleep-waking metaphor serves as a significant romantic image of self-actualization and resurrection (581).

The protagonist's affiliation with reverie, music, sleep, and ennui introduces to her the outlet to the world of the unconscious. The heroine of the unconscious, hence, Edna turns to a Jungian archetypal figure. According to Jung, actualizing the 'archetype' of the Self - or the quest Campbell would call myth of the hero - whose source is the collective unconscious drives the individual to explore the psychic thresholds of reality and the inner self (Adamsky 265).

Besides critical readings of the novel as the myth of Psyche (Franklin 510) or of Aphrodite (Gilbert 55), its archetypal quality can be disclosed by Biblical and mythical allusions in the text. The reference to Madame Ratignolle as "a faultless Madonna" (Chopin 15) or "some sensuous Madonna" (16) which confirms the Jungian archetype of the Great Mother, associated with life, birth, warmth, nourishment, protection, and fertility and symbolizing Edna's persona is a case in point (Stevens 89). Mademoiselle Reisz on the other hand represents the archetypal figure of the Terrible Mother, corresponding to the shadow concept with which Edna aspires but is unable to identify: "How Mademoiselle Reisz would 
have laughed, perhaps sneered, if she knew!" Edna ponders in the suicide episode, "And you call yourself an artist! What pretensions, Madame! The artist must possess the courageous soul that dares and defies" (Chopin 121).

The comparison Robert draws between Edna and the Biblical seven sleepers (Chopin 42), after her waking from the deep and peaceful slumber in paradisiac Grand Isle, emphasizes the idea of her heroic quest and the progressive awakening to her new self. Another occasion proves to be Victor's mythologizing of Edna at her party, commenting that "Venus rising from the foam could have presented no more entrancing a spectacle than Mrs. Pontellier, blazing with beauty and diamonds at the head of the board" (118). In fact, being her first publicized rebellious act of independence, the party is supposed to be her 'rite of passage,' the requisite stage for the hero's initiation (Beer and Nolan 113).

Moreover, the abundance of certain archetypal motifs promotes the mythological fabric of Chopin's writing. Based on Campbell's tripartite model of the hero myth, the journey is defined as a circular movement of initial separation and final recapitulation, together with the revelation and transformation in the initiatory middle stage (Smith vii). Consequently, images such as the bird and sea, and sun which are presented upon Edna's separation also appear in the return phase in order to contribute to the cyclic essence of the journey. The middle stage of psychic development, however, is introduced through different images of the moon, seasons, flowers, and trees while the basic motifs of the exposition and recapitulation phases are being simultaneously extended.

This circular pattern is strengthened by drawing a parallel between the vision of the naked man and the bird in the expository section of the quest and of the naked Edna and the similar bird imagery in her suicide scene: "He was naked. His attitude was one of hopeless resignation as he looked toward a distant bird winging its flight away from him" (Chopin 30). More precisely, bird flight's association with the hero's mission can be illustrated in light of Mademoiselle Reisz's examining Edna "to see if my wings were strong," since she believes "[t]he bird that would soar above the level plain of tradition and prejudice must have strong wings. It is a sad spectacle to see the weaklings bruised, exhausted, fluttering back to earth" (88); the image which brings Edna to her downfall: "A bird with a broken wing was beating the air above, reeling, fluttering, circling disabled down, down to the water" (120). It is not surprising then that Edna's personal utopia where she establishes her spiritual home (the declaration of independence) is named "pigeon house" (90).

The sea image, likewise, though resonating all throughout the novel $(10,15,16,18,20$, ...), lending it a hypnotic rhythm and melancholic lyricism, is brought to the fore in the opening and closing passages in order to highlight the circularity of the mythical passage: "The voice of the sea is seductive, never ceasing, whispering, clamoring, murmuring, inviting the soul to wander in abysses of solitude" $(18,120)$. Nevertheless the heroine's descent into the sea's "abysses of solitude" marks a fundamental departure from Campbell's theme of death and resurrection, that is descent into and return from the underworld, the same Jungian shadow, "wherein are hoarded all of the rejected, unadmitted, unrecognized, unknown, or undeveloped, factors, laws, and elements of existence" (Campbell 48); for Edna whose shock of disillusionment with reality of the romantic love is irremediable there would be no return: "The trouble is," Doctor Mandelet confirms, "that youth is given up to illusions. It seems to be a provision of Nature; a decoy to secure mothers for the race. And Nature takes no account of moral consequences, of arbitrary conditions which we create, and which we feel obliged to maintain at any cost" (Chopin 116).

The way Chopin ironizes the love of the 'Other' is reflected in Edna's relations with Alcee and Robert; "Chopin shrewdly designs the Alcee episode to present what will be Edna's 
greatest challenge: to understand that romantic love is born of the erotic longing within oneself for transcendence that cannot be fulfilled by union with another human being" (Franklin 523). Robert's love is not of more use either. Effeminate and in need for "whatever crumbs of sympathy and comfort" by being a "devoted attendant of some fair dame or damsel" since the age of fifteen (Chopin 14), he can be seen as Edna's archetypal Soul Mate. In other words, what Edna adores in Robert is the image of her own self and it is this same narcissistic infatuation which brings her to her demise in water.

\section{CONCLUSION}

The Awakening is the critique of romantic love much more than it is about the defeat of a feminine principal to go against the grain; it is concerned with the realistic demythologizing of the myths of hero and heroism rather than of violating social and moral taboos; it ironizes the failure of imagination to a greater degree than that of human individuals' primordial yearning for self-actualization. Nonetheless to Chopin, awakening, agonizing though it is and whatever the consequences, seems to be noble; in this sense the individual's willed suffering to exercise choice (even of death) would be a far worthier cause to live/die for: "The years that are gone seem like dreams - if one might go on sleeping and dreaming - but to wake up and find - oh! well! Perhaps it is better to wake up after all, even to suffer, rather than to remain" (Chopin 116).

\section{References}

[1] Adamski S. Adam., NeuroQuantology 9(3) (2011) 563-571.

[2] Beer Janet, Elizabeth Nolan. Kate Chopin's The Awakening : A Sourcebook. London: Routledge, 2004. Print.

[3] Bloom Harold. Introduction. Kate Chopin. Ed. Bloom. New York: Bloom's Literary Criticism, 2007. 1-6. Print.

[4] Campbell Joseph. The Hero with a Thousand Faces. Princeton: Princeton University Press, 2004. Print.

[5] Chopin Kate. The Awakening and Selected Short Stories. Pennsylvania: Pennsylvania State University, 2009. The Kate Chopin Archive. Web. 12 Mar. 2013.

[6] Franklin Rosemary F., American Literature 56(4) (1984) 510-526.

[7] Gilbert, Sandra M. "Edna as an Aphrodite Figure." Kate Chopin's The Awakening. Ed. Harold Bloom. New York: Bloom's Literary Criticism, 2008. 51-59. Print.

[8] Heilmann Ann. "The Awakening and New Woman Fiction." The Cambridge Companion to Kate Chopin. Ed. Janet Beer. Cambridge: Cambridge UP, 2008. 87-104. Print.

[9] Jung Carl. The Archetypes and the Collective Unconscious. Ed. Michael Fordham. Vol. 9. London: Routledge, 1954. Print.

[10] Knights Pamela. "Kate Chopin and the Subject of Childhood." The Cambridge Companion to Kate Chopin. Ed. Janet Beer. Cambridge: Cambridge UP, 2008. 44-58. 
[11] Ringe Donald A., American Literature 43(9) (1972) 580-588.

[12] Smith Evans Lansing. The Hero Journey in Literature: Parables of Poesis. Lanham: University Press of America, 1997. Print.

[13] Stevens, Anthony. Archetype: A Natural History of the Self. London: Routledge \& Kegan Paul, 1928. Print.

[14] Zhang Kai. "Archetype and Allegory in Journey to the West." Diss. University of Victoria, 2003. OhioLink. Web. 2 July 2013. 